\title{
STUDI TENTANG PRESTASI BELAJAR SISWA DALAM BERBAGAI ASPEK DAN FAKTOR YANG MEMPENGARUHI
}

\author{
Ahmad Syafi' ${ }^{1}{ }^{1}$ Tri Marfiyanto ${ }^{2}$ Siti Kholidatur Rodiyah ${ }^{3}$ \\ Program Studi Pendidikan Agama Islam Universitas Sunan Giri Surabaya ${ }^{1,3}$ \\ Pasca Sarjana Universitas Sunan Giri Surabaya ${ }^{2}$ \\ Email: karimahmadsyafii@gmail.com
}

\begin{abstract}
Abstrak
Artikel ini adalah hasil kajian pustaka melalui metode diskriftif kualitatif yang mengkaji tentang gambaran umum prestasi belajar siswa dari berbagai aspek dan faktor-faktor yang mempengaruhi sehingga dihasilkan sebuah kesimpulan bahwa terdapat tiga aspek prestasi dalam belajar siswa yaitu aspek kognitif dan aspek afektif serta aspek psikomotorik dengan dua faktor yang mempengaruhi sebuah hasil dari prestasi tersebut diantaranya adalah faktor internal seperti pertama faktor fisiologi kedua faktor psikologi ketiga faktor kematangan fisik maupun psikis sedangkan faktor eksternal diantaranya adalah pertama faktor sosial kedua faktor budaya dan ketiga faktor lingkungan.
\end{abstract}

Kata Kunci: prestasi belajar siswa, faktor-faktor yang mempengaruhi

\section{STUDY ABOUT STUDENT LEARNING ACHIEVEMENT ASPECT AND FACTORS AFFECTING}

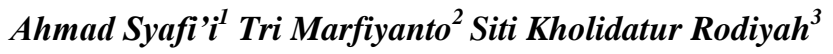 \\ Program Studi Pendidikan Agama Islam Universitas Sunan Giri Surabaya ${ }^{1,3}$ \\ Pasca Sarjana Universitas Sunan Giri Surabaya ${ }^{2}$
}

Email: karimahmadsyafii@gmail.com

\begin{abstract}
The manuscripts we compiled are the results of literature review through qualitative discriminative methods that examine the general description of student achievement of various aspects and factors that influence the resulting conclusion that there are three aspects of achievement in student learning are aspects of cognitive and affective aspects and psychomotor aspects with two factors influencing an outcome of that achievement among them are internal factors such as first factor physiology both psychological factors of the three factors of physical and psychological maturity while external factors are the first social factors of both cultural factors and the three environmental factors
\end{abstract}

Key Words: learning achievement, various aspects and factors 


\section{PENDAHULUAN}

Di dalam Undang-Undang No. 20 tahun 2003 tentang Sistem Pendidikan Nasional, bab 1 pasal 1 dikemukakan "Pendidikan adalah upaya sadar dan terencana untuk mewujudkan suasana belajar dan proses pembelajaran agar peserta didik secara aktif mengembangkan potensi dirinya untuk memiliki kekuatan spiritual keagamaan, pengendalian dirinya, kepribadian, kecerdasan, akhlak mulia, serta keterampilan yang diperlukan dirinya, masyarakat, bangsa dan negara." (Undang Undang Sistem Pendidikan Nasional, 2009).

Dewi Salma (Prawiradilaga, 2007). mengatakan tentang belajar "proses berfikir, terjadi secara internal didalam diri seorang untuk memahami dan mendalami suatu kemampuan atau kompetensi atau keahlian tertentu baik yang kasat mata maupun yang abstrak".

Prestasi belajar merupakan hasil belajar yang dicapai setelah melalui proses kegiatan belajar mengajar. Prestasi belajar dapat ditunjukkan melalui nilai yang diberikan oleh seorang guru dari jumlah bidang studi yang telah dipelajari oleh peserta didik. Setiap kegiatan pembelajaran tentunya selalu mengharapkan akan menghasilkan pembelajaran yang maksimal. Dalam proses pencapaiannya, prestasi belajar sangat dipengaruhi oleh berbagai faktor. Salah satu faktor utama yang sangat berpengaruh dalam keberhasilan pembelajaran adalah keberadaan guru. Mengingat keberadaan guru dalam proses kegiatan belajar mengajar sangat berpengaruh, maka sudah semestinya kualitas guru harus diperhatikan (Mulyasa, 2005).

Hasil Belajar merupakan penilaian pendidikan tentang perkembangan dan kemajuan murid berkenaan dengan penguasaan bahan pengajaran yang disajikan kepada mereka serta nilai-nilai yang terdapat dalam kurikulum.

Sumarni dan Bimo Budi Santoso serta Achmad Rantes Suparman dalam penelitiannya tentang hasil belajar dalam aspek kognisi menyimpulkan "Hasil penelitian menunjukkan bahwa ada perbedaan hasil belajar kognitif, model pembelajaran inkuiri terbimbing lebih baik dari model pembelajaran konvensional dengan persen pengaruh 29,49\% (Achmad Rantes, 2017).

Dalam hal ini lembaga pendidikan, merupakan wadah bagi masyarakat sebagai sarana untuk melatih dan mendidik seseorang agar mampu berkembang secara efektif, terutama pada kehidupan yang modern seperti sekarang. Tuntutan akan menjadi manusia yang progresif (berkembang), menjadikan orang tua mempercayakan lembaga pendidikan sebagai wadah untuk bisa mengembangkan potensi putra putrinyanya. Dalam hal ini, adanya suatu perhatian lebih tentang pendidikan, bisa dikatakan juga 
adanya sebuah prioritas bagi lembaga pendidikan untuk mengembangkan potensi masyarakat melalui lembaga pendidikan tersebut (Djamaroh, 2002).

Lebih lanjut naskah ini merupakan kajian literasi sebagai metode untuk mendapatkan data dari para ahli tentang prestasi belajar serta aspek yang mempengaruhi yang selanjutnya dianalisis dimana simpulannya agar dapat dijadikan rujukan oleh para praktisi pendidikan dalam mengembangkan peningkatan hasil belajar siswa.

\section{KAJIAN TEORITIS}

\section{Prestasi Belajar}

Istilah prestasi belajar terdiri dari dua kata, yaitu prestasi dan belajar. Istilah prestasi di dalam Kamus Ilmiah Populer didefinisikan sebagai hasil yang telah dicapai. Menurut Noehi Nasution, menyimpulkan bahwa "belajar dalam arti luas dapat diartikan sebagai suatu proses yang memungkinkan timbulnya atau berubahnya suatu tingkah laku sebagai hasil dari terbentuknya respons utama, dengan syarat bahwa perubahan atau munculnya tingkah baru itu bukan disebabkan oleh adanya perubahan sementara karena sesuatu hal" (Wahab, 2015).

Prestasi merupakan kumpulan hasil akhir dari suatu pekerjaan yang telah dilakukan. Menurut Djamarah (2002: 19), "Prestasi adalah suatu kegiatan yang telah dikerjakan, diciptakan baik secara individual maupun kelompok".

Sementara itu, Muhibbin Syah sebagaimana yang diungkap Rohmalina Wahab, Psikologi Belajar, mengutip pendapat dari beberapa pakar psikologi tentang definisi belajar, di anataranya adalah: a) Skinner, seperti yang dikutip Barlow dalam bukunya Educational psychology: The Teaching Learning Process, berpendapat bahwa belajar adalah suatu proses adaptasi atau penyesuaian tingkah laku yang berlangsung secara progresif ( a process of progressive behavior adaptation); b) Hintzman dalam bukunya The Psychology of Learning and Memory berpendapat Learning is change in organism due to experience which can affect the organism's behavior. Artinya, belajar adalah suatu perubahan yang terjadi dalam diri organisme (manusia dan hewan) disebakan oleh pengalaman yang dapat mempengaruhi tingkah laku organisme tersebut; c) Witting dalam bukunya, Psychology of Learning, mendefinisikan belajar sebagai: any relatively permanent change in an organisme's behavioral repertoire that occurs as a result of experience. Belajar ialah perubahan yang relatif menetap terjadi dalam segala macam/keseluruhan tingkah laku suatu organisme sebagai hasil pengalaman; d) Biggs, dalam pendahuluan buku Teaching of Learning, mendefinisikan belajar dalam tiga rumusan, yaitu rumusan kuantitatif, rumusan 
institusional, dan rumusan kualitatif (Wahab, 2015).

Secara Kuantitatif (ditinjau dari sudut jumlah), belajar berarti kegiatan pengisian atau pengembanagan kemampuan kognitif dengan fakta sebanyak-banyaknya. Jadi, belajar dapat dipandang sebagai sudut dari berapa banyak materi yang telah dikuasai oleh siswa. Secara Institusional (tinjauan kelembagaan), belajar dipandang sebagai proses "Validasi" atau pengabsahan terhadap penguasaan siswa atas materi-materi yang telah ia pelajari. Bukti institusional yang menunjukkan siswa telah belajar dapat diketahui sesuai dengan proses mengajar. Ukurannya semakin baik mutu guru mengajar akan semakin baik pula mutu perolehan pelaku belajar yang kemudian dinyatakan dalam skor. Adapun pengertian belajar secara Kualitatif (tinjauan mutu), ialah proses memperoleh arti-arti dan pemahamanpemahaman serta cara-cara menafsirkan dunia di sekeliling pelaku belajar. Belajar dalam pengertian ini difokuskan pada tercapainya daya pikir dan tindakan yang berkualitas untuk memecahkan masalahmasalah yang kini dan nanti akan dihadapi oleh pelaku belajar (Wahab, 2015, hal. 243).

Ngalim Purwanto berpendapat bahwa prestasi belajar adalah kemampuan maksimal dan tertinggi pada saat tertentu oleh seorang anak dalam rangka mengadakan hubungan rangsang dan reaksi yang akhirnya terjadi suatu proses perubahan untuk memperoleh kecakapan dan ketrampilan" (Purwanto, 1997).

Menurut (Djamaroh, 2002, hal. 231), "prestasi adalah hasil kegiatan usaha belajar yang dinyatakan dalam bentuk, angka, huruf, maupun kalimat yang dapat mencerminkan hasil yang telah dicapai oleh setiap siswa". Sementara Siti Pratini berpendapat pestasi "adalah suatu hasil yang dicapai seseorang dalam melakukan kegiatan belajar" (Pratini, 2005)

Berdasarkan beberapa pendapat di atas, dapat disimpulkan bahwa prestasi belajar adalah serangkaian dari kegiatan jiwa raga yang telah dilakukan oleh seseorang dari suatu hasil yang telah dicapai sebagai perubahan dari tingkah laku yang dilalui dengan pengalaman serta wawasan untuk bisa berinteraksi dengan lingkungan yang menyangkut ranah kognitif, afektif dan psikomotorik yang telah dinyatakan dalam hasil akhir/raport.

\section{Aspek-aspek Prestasi Belajar Siswa}

Hasil sebuah prestasi dari belajar tentunya memiliki aspek yang bisa menjadi indikator terhadap pencapaian dalam belajar. Aspek-aspek tersebut setidaknya ada tiga (3) aspek prestasi belajara yang ketiganya dapat dikaji dalam berbagai literasi.

Pertama adalah aspek kognitif. Aspek kognitif sebagai indikator dalam pencapaian 
sebuah prestasi hal ini seperti yang disampaikan oleh Muhibbin Syah bahwa "untuk mengukur prestasi siswa bidang kognitif ini dapat dilakukan dengan berbagai cara, baik dengan tes tulis maupun tes lisan". (Syah, 2001).

"Hasil belajar dalam tingkatan ini merupakan hasil belajar yang tertinggi dalam ranah (domain) kognitif, sehingga memerlukan tipe hasil belajar yang lebih tinggi dari tingkatan sebelumnya (pengetahuan, pemahaman, aplikasi, analisis, sentesis)" (Syaodih, 1996).

Aspek kognitif dapat dikelompokkan menjadi (enam) tingkatan yaitu; (1) Tingkat pengetahuan (knowledge), Tujuan instruksional pada level ini menuntut siswa untuk mengingat (recall) informasi yang teah diterima sebelumnya, misalnya fakta, terminologi pemecahan masalah dan sebagainya; (2) Tingkat pemahaman (komprehensip), Kategori pemahaman dihubungkan dengan kemampuankemampuan untuk menjelaskan pengetahuan, informasi yang telah diketahui dengan katakata sendiri. Dalam hal ini siswa diharapkan menerjemahkan atau menyebeutkan kembali apa yang telah didengar dengan kata-kata; (3) Tingkat Penerapan (aplicatioan), Penerapan merupakan kemampuan untuk menggunakan atau menerapkan informasi yang telah dipelajari ke dalam situasi yang baru, serta memecahkan berbagai masalah yang timbul dalam kehidupan sehari-hari; (4) Tingkat Analisis (analysis), Analisis merupakan kemampuan untuk mengidentifikasi, memisahkan dan membiarkan komponenpomponen atau elemen-elemen suatu fakta, konsep, pendapat, asumsi, hipotesa atau kesimpulan dan memeriksa komponenkomponen tersebut untuk melihat atau tidaknya kontradiksi. Dalam hal ini siswa diharapkan dapat menunjukkan hubungan diantara berbagai gagasan dengan cara membandingkan gagasan tersebut standart prinsip atau prosedur yang telah dipelajari; (5) Tingkat sintesis (syinthesis), Sisntesis diartikan sebagai kemampuan seseorang dalam mengaitkan dan menyatukan berbagai elemen dan unsur pengetahuan yang ada sehingga terbentuk pola baru yang menyeluruh; (6) tingkat evaluasi (evaluation), Evaluasi merupakan level tertinggi yang mengharapkan siswa mampu membuat penilaian dan keputusan tentang nilai gagasan metode produk atau benda dengan menggunakan kriteria tertentu. Jadi evaluasi disini lebih condong berbentuk penilaian biasa dari pada penilaian evaluasi (Sujana, 2005).

Kedua adalah aspek afektif. Aspek afektif ialah ranah berfikir yang meliputi watak perilaku seperti perasaan, minat, sikap, emosi, atau nilai. Menurut Harun Rasyid dan Mansur "ranah afektif menentukan keberhasilan belajar seseorang. Orang yang 
tidak memiliki minat pada pelajaran tertentu sulit untuk mencapai keberhasilan studi secara optimal. Seseorang yang berminat dalam suatu mata pelajaran diharapkan akan mencapai hasil pembelajaran yang optimal (Rasyid \& Mansur, 2007).

Muhibbin Syah mengatakan "Prestasi yang bersifat afektif yaitu meliputi penerimaan sambutan, apresiasi (sikap menghargai), internalisasi (pendalaman), karakterisasi (penghayatan). Misal seorang siswa dapat menunjukkan sikap menerima atau menolak terhadap suatu pernyataan dari permasalahan atau mungkin siswa menunjukkan sikap berpartisipasi dalam hal yang dianggap baik (Syah, 2004).

Ketiga adalah Aspek psikomotorik. Psikomotorik merupakan aspek yang berhubungan dengan olah gerak seperti yang berhubungan dengan otot-otot syaraf misalnya lari, melangkah, menggambar, berbicara, membongkar peralatan atau memasang peralatan dan lain sebagainya.

Harun Rasyid dan Mansur mengatakan "Gerakan dasar adalah gerakan yang mengarah pada keterampilan komplek yang khusus. Siswa yang telah mencapai kompetensi dasar pada ranah ini mampu melakukan tugas dalam bentuk keterampilan sesuai dengan standar atau kriteria" (Rasyid \& Mansur, 2007).

Pencapaian prestasi belajar atau hasil belajar siswa dapat digolongkan menjadi beberapa aspek seperti; aspek kognitif, aspek afektif dan aspek psikomotorik.

Dengan kata lain bahwa ketiga aspek prestasi belajar tersebut yaitu: yang meliputi aspek afektif, aspek kognitif dan aspek psikomotorik akan lebih sempurna jikalau ketiga aspek tersebut di miliki oleh setiap siswa. Sehingga siswa tidak hanya cerdas dalam mata pelajaran namun juga cerdas dalam menerapkan pada kehidupan seharihari. Capaian prestasi belajar tidak bisa berdiri sendiri, akan tetapi selalu berhubungan satu sama lain.

\section{Faktor-Faktor yang Mempengaruhi Prestasi Belajar}

Suatu prestasi hasil dalam belajar di sekolah merupakan hasil upaya belajar yang sangat banyak dipengaruhi dengan kemampuan secara umum yang dapat kita diukur. Pengukuran kemampuan secara umum tersebut salah satunya dapat melalui Intellegence Quotient (IQ). Karena dengan IQ yang relatif tinggi akan mampu meramalkan suatu kesuksesan prestasi dalam belajar. Tetapi meskipun demikian pada beberapa hal kasus IQ yang tinggi ternyata tidak menjamin kesuksesan seseorang dalam belajar dan hidup tengah-tengah bermasyarakat.

Rohmalia Wahab mengemukakan bahwa IQ bukanlah satu-satunya faktor penentu kesuksesan prestasi belajar seseorang. Ada "faktor-faktor yang 
mempengaruhi prestasi belajar anak dan kurikulum berbasis kompetensi di Sekolah Dasar" faktor-faktor lain yang turut andil mempengaruhi perkembangan prestasi belajar. Faktor-faktor yang mempengaruhi pretasi belajar adalah antara lain sebagai berikut : (1) Pengaruh pendidikan dan pembelajaran unggul; (2) Perkembangan dan pengukuran otak, dan (3) Kecerdasan (intelegensi) emosional (Wahab, 2015, hal. 247-248).

Prestasi belajar yang telah dicapai oleh seseorang merupakan hasil interaksi sebagai faktor yang mempengaruhinya baik dari dalam diri (faktor internal) maupun dari luar diri (faktor eksternal) individu. Pengenalan terhadap faktor-faktor yang mempengaruhi prestasi belajar sangat penting sekali. Artinya supaya bisa membantu murid dalam mencapai prestasi belajar yang sebaikbaiknya.

Terkait faktor intern Sumadi Surya Brata, mengatakan bahwasannya "faktor intern terdiri dari fisiologis yang merupakan keadaan jasmani terutama panca indera sebagai pintu gerbang masuknya pengaruh dari luar dan psikologis" (Brata, 1998).

Abu Ahmadi dan Widodo Supriyono merinci faktor yang mempengaruhi prestasi dalam belajar digolongkan secara rinci menjadi dua faktor yaitu internal dan eksternal. Pertama "Faktor internal ; (1). Faktor jasmani (fisiologi). Misalnya penglihatan, pendengaran, struktur tubuh dan sebagainnya; (2). Faktor psikologi, antara lain; (a). Faktor intelektif yang meliputi: faktor potensial yaitu kecerdasan, bakat dan faktor kecakapan nyata yaitu prestasi yang telah dimiliki, (b). Faktor non intelektif, yaitu unsur-unsur kepribadian tertentu seperti sikap, kebiasaan, minat, kebutuhan, motivasi, emosi; (3). Faktor kematangan fisik maupun psikis (Ahmadi \& Supriyono, 2011).

Kedua Faktor Eksternal ; (1). Faktor sosial yang terdiri atas; (a). Lingkungan keluarga, (b). Lingkungan sekolah, (c). Lingkungan masyarakat, (d). Lingkungan kelompok; (2). Faktor budaya seperti adat istiadat, ilmu pengetahuan, teknologi, kesenian; (3). Faktor lingkungan fisik seperti fasilitas rumah, fasilitas belajar, iklim (Ahmadi \& Supriyono, 2011).

$\begin{array}{rlrr}\text { Menurut } & \text { Slameto dalam bukunya } \\ \text { berpendapat } & \text { bahwa } & \text { faktor yang }\end{array}$ mempengaruhi belajar siswa terdapat beberapa jenis, tetapi hanya digolongkan menjadi dua jenis saja, yaitu faktor intern dan faktor ekstern. Faktor intern adalah faktor yang ada dalam diri individu yang sedang belajar, sedangkan faktor ekstern adalah faktor yang ada diluar individu. Faktor-faktor intern meliputi : (1). Faktor Jasmaniah; (a). Faktor kesehatan, (b). Cacat tubuh; (2). Faktor psikologis; (a). Intelegensi, (b), Perhatian, (c). Minat, (d), Bakat, (e). Motif, (f). Kematangan, (g). Kesiapan; (3). Faktor 
kelelahan. Faktor-faktor ekstern meliputi : (1). Keadaan keluarga; Keluarga merupakan lingkungan utama dalam proses belajar. Keadaan yangada dalam keluarga mempunyai pengaruh yang besar dalam pencapaian prestasi belajar misalnya cara orang tua mendidik, relasi anggota keluarga, suasana rumah, keadaan ekonomi keluarga, pengertian orang tua, (2). Keadaan sekolah; Lingkungan sekolah adalah lingkungan di mana siswa belajar secara sistematis. Kondisi ini meliputi metode mengajar, kurikulum, relasi guru dengan siswa, relasi siswa dengan siswa, disiplin sekolah, alat pelajaran, metode belajar danfasilitas yang mendukung lainnya, (3). Keadaan masyarakat; Siswa akan mudah kena pengaruh lingkungan masyarakat karena keberadaannya dalam lingkungan tersebut. Kegiatan dalam masyarakat, mass media, teman bergaul, lingkungan tetangga merupakan hal-hal yang dapat mempengaruhi siswa sehingga perlu diusahakan lingkungan yang positif untuk mendukung belajar siswa (Slameto, 2010). "Perlu kesungguhan guru pula dalam menggunakan teknik pembelajaran dan media pembelajaran yang inovatif sehingga dapat terlaksana proses belajar mengajar yang baik dan berhasil" (Widyahening, 2018).

Jadi, guru kedua faktor yang mepengaruhi prestasi belajar siswa yang meliputi faktor intern dan ekstern yang ada dalam diri individu tidak dapat dipisahkan, karena ke dua faktor tersebut saling berinteraksi secara langsung maupun tidak langsung dalam proses belajar untuk mencapai prestasi belajar siswa denan tidak menafikan keterlibatan kesungguhan seorang guru.

\section{SIMPULAN DAN SARAN}

Kesimpulan dari studi analisis ini adalah bahwa prestasi belajar dapat dikelompokkan kedalam tiga aspek prestasi yaitu aspek kognitif, aspek afektif dan aspek psikomotorik. Aspek kognitif ini berhubungan dengan proses berpikir pada mata pelajaran yang diperoleh melalui hasil evaluasi dalam bentuk nilai baik harian, tugas-tugas rumah, dan bentuk ulangnganulangan lainnya dalam semester. Maka prestasi bidang kognitif ini menekankan pada bidang intelektual, sehingga kemampuan akal selalu mendapatkan perhatian yakni kerja otak dapat menguasai berbagai pengetahuan yang diterimanya Prestasi belajar aspek afektif berkaiatan erat dengan nilai atau sikap yang diperoleh dari sikap siswa selama proses belajar mengajar terhadap permasalahan yang berkaitan dengan mata pelajaran. Aspek afektif ini sudah barang tentu mempunyai nilai yang tinggi karena didalamnya menyangkut kepribadian siswa. Prestasi belajar aspek psikomotorik berakaitan erat perbuatan yang diperoleh dengan cara bagaimana siswa dalam mempraktekkan 
materi mata pelajaran dalam kehidupan sehari-hari, baik di rumah, di sekolah mapun di lingkungan masyarakat.

Adapun suatu prestasi belajar siswa dapat dipengaruhi oleh berbagai hal tetapi dapat digolongkan menjadi dua faktor utama yaitu pertama faktor intern dan kedua faktor ekstern. Faktor intern ini berasal dari dalam diri siswa itu sendiri seperti Faktor jasmani (fisiologi), Faktor psikologi, dan Faktor kematangan fisik maupun psikis kematangan atau pertumbuhan. Sedangkan faktor ekstern ini faktor yang brasal dari luar diri siswa misalnya kondisi/keadaan keluarga, keadaan/kondisi sekolah, keadaan/kondisi lingkungan masyarakatnya.

Saran penulis bagi praktisi pendidikan bahwa tiga aspek prestasi yang terdiri dari kognitif, afektif dan psikomotorik serta dua faktor yang mempengaruhi prestasi belajar siswa tersebut yakni faktor intern dan faktor ekstern selayaknya diperhatikan oleh seorang pendidik untuk menentukan langkah mengambil tindakan dalam proses pembelajaran.

\section{DAFTAR PUSTAKA}

Achmad Rantes, S. B. (2017). Pengaruh Model Pembelajaran Inkuiri Terbimbing Terhadap Hasil Belajar Kognitif Peserta Didik. Diambil kembali dari Journal Komunikasi
Pendidikan:

http://journal.univetbantara.ac.id/index.php/k omdik/article/view/17

Ahmadi, A., \& Supriyono, W. (2011). Psikologi Belajar. Jakarta: Rineka Cipta.

Brata, S. S. (1998). Psikologi Pendidikan. Jakarta: PT. Raja Grafindo Persada.

Djamaroh, S. B. (2002). Strategi Belajar Mengajar. Jakarta: Rineka Cipta.

Mulyasa, E. (2005). Menjadi Guru Profesional. Bandung: Remaja Rosda Karya.

Pratini, S. (2005). Psikologi Pendidikan. Yogyakarta: Studing.

Prawiradilaga, D. S. (2007). Prinsip Desain Pembelajaran. Jakarta: Kencana Prenada Media Group.

Purwanto, N. (1997). Psikologi Pendidikan. Bandung: PT. Remaja Rosda Karya.

Rasyid, H., \& Mansur. (2007). Penilaian Hasil Belajar. Bandung: Wacana Prima.

Slameto. (2010). Belajar dan Faktor-Faktor Yang Mempengaruhinya. Jakarta: PT. Rineka Cipta.

Sujana, N. (2005). Penilaian Hasil Proses Belajara Mengajar. Bandung: Remaja Rosda Karya.

Syah, M. (2001). Psikologi Belajara. Jakarta: Raja Grafindo.

Syah, M. (2004). Psikologi Belajar. Jakarta: PT. RajaGrafindo Persada.

Syaodih, R. N. (1996). Perencanaan Pengajaran. Jakarta: Renika Cipta.

Undang Undang Sistem Pendidikan Nasional. (2009). Undang-Undang Sistem Pendidikan Nasional No. 20 Tahun 2003 Tentang Sistem Pendidikan Nasional. Bandung: Rhusty Publisher.

Wahab, R. (2015). Psikologi Belajar. Jakarta: PT RajaGrafindo Persada.

Widyahening, C. E. (2018). PENGGUNAAN TEKNIK PEMBELAJARAN FISHBONE DIAGRAM DALAM MENINGKATKAN KETERAMPILAN MEMBACA SISWA. Dipetik 06 26, 2018, dari Jurnal Komunikasi Pendidikan: http://journal.univetbantara.ac.id/index.php/k omdik/article/view/59 